\title{
SUPERVISI PENGAJARAN UNTUK MENINGKATKAN PROFESIONALISME GURU DI SEKOLAH DASAR \\ (Studi Multikasus di SD Laboratorium Sumber Ilmu,SDN Sekar Arum I, SDK Sang Surya, San SON Madukoro VI, Malang)
}

\author{
Roemintoyo \\ Prodi. Pend. Teknik Bangunan, Jurusan Pendidikan Teknik dan Kejuruan, FKIP, UNS \\ Kampus UNS Pabelan Jl. Ahmad Yani 200, Surakarta, Telp/Fax 0271718419
}

\begin{abstract}
ABSTRAK
Tujuan penelitian ini adalah untuk mendeskripsikan program supervisi pengajaran untuk meningkatkan profesionalisme guru di sekolah dasar. Temuan penelitian menunjukkan bahwa dalam rangka meningkatkan profesionalisme guru, Kepala Sekolah melalui supervisi pengajaran melaksanakan upaya-upaya sebagai berikut: melaksanakan kunjungan kelas, monitoring KBM, rapat dewan guru, pembinaan secara individu maupun kelompok, bacaan profesional, studi lanjut, mengikutkan guru dalam KKG, penataran/lokakarya/seminar, sharing dan diskusi antar guru, guru dengan kepala sekolah, guru dengan pengawas.
\end{abstract}

Kata kunci: supervisi pengajaran, profesionalisme guru, kepala sekolah.

\section{PENDAHULUAN}

Penyelenggaraan pendidikan nasional merupakan realisasi dari amanat Pembukaan UUD 1945 yaitu mencerdaskan kehidupan bangsa. Pasal 31 ayat (1) Setiap warga negara berhak mendapat pendidikan, (2) Setiap warga negara wajib mengikuti pendidikan dasar dan pemerintah wajib membiayainya, (3) Pemerintah mengusahakan dan menyelenggarakan satu sistem pendidikan nasional, yang mening-katkan keamanan dan ketaqwaan serta akhlak mulia dalam rangka mencerdaskan kehidupan bangsa, yang diatur dengan undang-undang, (4) Negara memprioritaskan anggaran pendidikan sekurangkurangnya dua puluh persen dari anggaran pendapatan dan belanja negara serta dari anggaran pendapatan dan belanja daerah untuk memenuhi kebutuhan penyelenggaraan pendidikan nasional, dan (5) Pemerintah memajukan ilmu pengetahuan dan teknologi dengan menjunjung tinggi nilai-nilai agama dan persatuan bangsa untuk kemajuan peradaban serta kesejahteraan umat manusia. Pernyataan ini menunjukkan komitmen pemerintahdalam menyelenggarakan pendidikan nasional bagi seluruh bangsa Indonesia. Disamping itu, dalam Undang-Undang Nomor 20 Tahun 2003 tentang Sistem Pendidikan Nasional ditegaskan bahwa jalur pendidikan terdiri atas pendidikan formal, nonformal, dan informal yang dapat saling melengkapi dan memperkaya (Pasal 13 ayat 1). Jenjang pendidikan formal terdiri atas pendidikan dasar, pendidikan menengah, dan pendidikan tinggi. Pada bagian kedua tentang pendidikan dasar, dijelaskan bahwa (1) pendidikan dasar merupakan jenjang pendidikan yang melandasi jenjang pendidikan menengah, dan (2) pendidikan dasar berbentuk Sekolah Dasar (SD) dan Madrasah Ibtidaiyah (MI) atau bentuk lain yang sederajat serta Sekolah Menengah Pertama (SMP) dan Madrasah Tsanawiyah (MTs), atau bentuk lain yang sederajat.

Sebagai salah satu jenjang pendidikan, keberadaan pendidikan dasar merupakan landasan dari semua jenjang persekolahan dan pendidikan selanjutnya.Menurut Sidi (2001) pendidikan dasar mempunyai beberapa tujuan, yang mungkin berbeda antara satu negara dengan negara lainnya. Walaupun demikian, ada beberapa tujuan pokok pendidikan dasar pada semua situasi, yaitu mempersiapkan anak didik menjadi: (1) orang yang bermoral, (2) seorang warga negara, dan (3) orang dewasa yang mampu memperoleh pekerjaan dengan cara memberikan keterampilan dasar yang umum bagi semua pekerjaan di dalam suatu masyarakat kepada anak didik (Sidi, 2001).

Secara lebih khusus pentingnya sekolah dasar adalah untuk mengembangkan kemampuan siswa dalam hal dasar-dasar pengetahuan IPA, matematika, Bahasa, kesenian dan ilmu pengetahuan sosial. Hal ini seperti dikemukakan oleh Collier, Houston, Schmatz \& Walsh (1971:27) sebagai berikut ini:

Elementary schools must concern themselves with the important objectives of helping youngsters develop a valid 
foundation in such fundamental and important areas as science, mathematics, reading, language, fine arts, and social science.

Di Indonesia pendidikan dasar telah diatur oleh Undang-Undang Republik Indonesia No. 20 Tahun 2003 tentang Sistem Pendidikan Nasional (Sisdiknas). Dijelaskan dalam Bab VI, Bagian Kedua, Pendidikan Dasar, Pasal 17 bahwa (1) pendidikan dasar merupakan jenjang pendidikan yang melandasi jenjang pendidikan menengah, (2) pendidikan dasar berbentuk Sekolah Dasar (SD) dart Madrasah Ibtidaiyah (MI) atau bentuk lain yang sederajat serta Sekolah Menengah Pertama (SMP) dan Madrasah Tsanawiyah (MTs), atau bentuk lain yang sederajat, (3) ketentuan mengenai pendidikan dasar sebagaimana dimaksud dalam ayat (1) dan ayat (2) diatur lebih lanjut dengan Peraturan Pemerintah (Sisdiknas, 2003).

Sidi (2001) mengemukakan bahwa sebagai salah satu bentuk pendidikan dasar, sekoiah dasar merupakan satuan pendidikan yang paling urgen keberadaannya.Setiap orang mengakui bahwa tanpa menyelesaikan pendidikan pada jenjang sekolah dasar atau yang sederajat, secara formal seseorang tidak mungkin dapat mengikuti pendidikan pada jenjang berikutnya.

Menurut Danim (2003) persoalan utama pengelolaan SD saat ini tidak terletak pada efisiensinya, akan tetapi juga masalah mutu, akses, dan peluang pengembangan. Kajian Danim (2003) lebih lanjut, mengemukakan lemahnya efisiensi SD, umumnya, dan rendahnya basil belajar murid SD, khususnya, disebabkan oleh beberapa faktor. Hasil studi antara tahun 1960-an sampai dengan tahun 1990-an yang dilakukan oleh beberapa ahli menemukan beberapa kesimpulan. Pertama, di Negara-negara raj u, prestasi akademis lebih banyak diterangkan olehfaktor-faktor luar sekolah (SES, aspirasi keluarga, interaksi anak orang tua) dibandingkan dengan faktor sekolah itu sendiri.Kedua, di negara-negara sedang berkembang atau belum berkembang, prestasi belajar akademis lebih banyak diterangkan oleh faktor-faktor sekolah (guru, buku paket, alat belajar, manajemen sekolah, dan sebagainya) daripada oleh faktor luar sekolah.

Dari berbagai indikator yang diungkapkan tersebut, yang menjadi penyebab rendahnya mutu pendidikan ditinjau dan aspek manajemen pendidikan dapat dikelompokkan ke dalam tiga faktor, yaitu: (a) faktor instrumental sistem pendidikan, (b) faktor sistem manajemen pendidikan, termasuk di dalamnya sistem pembinaan profesional guru, dan (c) faktor substansi manajemen pendidikan (Mantja, 1993; 1996; 1998). Sedangkan Mataheru (1988) menekankan bahwa salah satu faktor yang perlu diperhatikan di sekolah dalam meningkatkan mutu tersebut adalah peningkatan performansi tenaga pendidik atau kemampuan profesional guru (Depdikbud, 1986).

Paradigma peningkatan tenaga pendidik pada saat ini memberikan wacana baru dalam implementadi kebijakan pemerintah melalui Departemen Pendidikan Nasional.Salah satu upaya untuk memberikan tolok ukur mutu tenaga pendidik adaah dengan diterbitkannya Peraturan Pemerintah Republik Indonesia Nomor 19 Tahun 2005 tentang Standar Nasional Pendidikan.

Dalam PP Nomor 19 Tahun 2005, pada Bab VI, Bagian Kesatu: Pendidik Pasal 28 dirumuskan secara lengkap standar tenaga pendidik sebagai berikut:

1. Pendidik harus memiliki kualifikasi akademik dan kompetensi sebagai agen pembelajaran, sehat jasmani dan rohani, serta, memiliki kemampuan untuk mewujudkan tujuan pendidikan nasional,

2. Kualifikasi akademik sebagaimana dimaksud pada ayat (1) adalah tingkat pendidikan minimal yang harus dipenuhi oleh seorang pendidikyang dibuktikan dengan ijazah dan/atau sertifikat keahlian yang relevan sesuai ketentuan perundangundangan yang berlaku,

3. Kompetensi sebagai agen pembelajaran pada jenjang pendidikan dasar dan menengah serta pendidikan anak usia dini meliputi:

a. Kompetensi pedagogik;

b. Kompetensi kepribadian;

c. Kompetensi profesional; dan

d. Kompetensi sosial.

4. Seseorang yang tidak memiliki ijazah dan/atau sertifikat keahlian khusus yang diakui dan diperlukan dapat diangkat menjadi pendidik setelah mele-wati Fuji kelayakan dan kesetaraan, dan

5. Kualifikasi akademik dan kompetensi sebagai agen pembelajaran sebagaimana dimaksud pada ayat (1) sampai dengan (4) dikembangkan oleh BSNP dan ditetapkan dengan Peraturan Menteri (Depdiknas, 2005). 
Berdasarkan rumusan di atas, dapat dikemukakan bahwa tenaga pendidik sebagai agen pembelajaran pada jenjang pendidikan dasar dituntut untuk memiliki seperangkat kompetensi yang dipersyaratkan, yaitu (1) kompetensi pedagogik, (2) kom-petensi kepribadian, (3) kompetensi profesional, dan (4) kompetensi sosial.

Produk kebijakan lainnya, yang secara khusus mengkaji mengenai tenaga pendidik dan telah disosialisasikan di berbagai instansi yang relevan adalah Undang-Undang Republik Indonesia Nomor 14 Tahun 2005 tentang Guru dan Dosen. Dalam undang-undang ini secara lebih lengkap dirumuskan mengenai prinsip profesionalisme, guru dan dosen. Hal-hal yang berkaitan dengan profesi guru, khususnya dalam hubungannya dengan kompetensi guru, dalam Bab IV Guru, Bagian Kesatu: kualifikasi, kompetensi, dan sertifikasi dirumuskan sebagai berikut

Tentang kualifikasi guru, dalam UU No. 14 Tahun 2005 ini dirumuskan dalam Pasal 8 yang menegaskan bahwa guru wajib memiliki kualifikasi akademik, kompetensi sertifikat pendidik, sehat jasmani dan rohani, serta memiliki kemampuan untuk mewujudkan tujuan pendidikan nasional. Sedangkan yangdimaksud dengan kualifikasi akademik tersebut di jelaskan dalam Pasal 9 yang menjelaskan bahawa kualifikasi akademik sebagaimana dimaksud dalam Pasal 8 diperoleh melalui pendidikan tinggi program sarjana atau program diploma empat. Adapun yang dimaksud dengan kompetensi guru dijelaskan dalam Pasal 10 ayat (1) yaitu bahwa kompetensi guru sebagaimana dimaksud dalam Pasal 8 meliputi kompetensi pedagogik, kompetensi kepribadian, kompetensi sosial, dan kompetensi profesional yang diperoleh melalui pendidikan profesi. Selanjutnya sertifikat pendidik sebagai-mana yang dimaksud dalam Pasal 8 diberikan kepada guru yang telah memenuhi persyaratan.

Apabila dikaji dan kedua produk kebijakan di atas, yaitu PP No. 19 Tahun 2005 dan UU No. 14 Tahun 2005 Guru dan Dosen, terdapat persamaan dalam merumuskan kompetensi guru yang dipersyaratkan. Kompetensi guru yang dipersyaratkan adalah (a) kompetensi pedagogik; (b) kompetensi kepribadian; (c) kompetensi profesional; dan (d) kompetensi sosial. Perangkat kompetensi bagi guru ini dirumuskan dalam PP No. 19 Tahun 2005 dan UU No. 114 Tahun 2005.
Diskusi tentang rincian kualifikasi tenaga pendidikan, dalam hal ini guru di sekolah, juga menarik para pakar pendidikan. Salah satu pakar pendidikan, Danim (2003) mengemukakan bahwa kualifikasi yang dimiliki oleh tenaga pendidikan dapat dikelompokkan ke dalam empat jenis, yaitu: (1) fisik, (2) pribadi, (3) profesional, dan (4) sosial. Kualifikasi yang pertama berkaitan dengan aspek-aspek kesehatan fisik, ciri-ciri khusus fisik, dan daya dukung kemampuan verbal.Kualifikasi kedua, berka-itan dengan aspek-aspek kepribadian tenaga pengajar, seperti keimanan, kepribadian sebagai insan Pancasilais, dan normal secara kejiwaan.Kualifikasi ketiga, berkenaan dengan tugas-tugas teknis pengajaran danpenguasaan materi bahan ajar dengan segala perangkat pendukungnya yang terkait langsung, serta kemampuannya mencip-takan kondisi anak didik menjadi masyarakat belajar (learning society) yang kian dirasakan mendesak pada era globalisasi ekonomi dan informasi.Selanjutnya, kualifikasi keempat berkaita dengan fungsi tenaga pendidikan sebagai bagian integral dari anggota masyarakat Indonesia yang Pancasilais.

Wacana masyarakat belajar (learning society) sebagaimana yang dikemukakan Danim di atas, sesuai dengan visi Depdiknas yang lebih menekankan pada pendidikan transformatif, yang menjadikan lembaga pendidikan sebagai motor penggerak perubahan dari masyarakat tradisional ke masyarakat maju. Masyarakat maju selalu diikuti oleh proses transformasi struktural, yang menandai suatu perubahan dari masyarakat yang bertumpu pada pertanian menuju masyarakat berbasis industri. Bahkan di era global sekarang, transformasi itu berjalan dengan sangat cepat yang kemudian mengantarkan pada masyarakat berpengetahuan (knowledge society).Di dalam masyarakat berpengetahuan, peranan ilmu pengetahuan dan penggunaan Information and Communication Technology (ICT) sangat dominan (Depdiknas, 2005).Walaupun demikian, masyarakat Indonesia yang sebagian besar masih berciri agraris belum sepenuhnya mampu memanfaatkan iptek yang mengalami perkembangan pesat dan menjadi penggerak utama (prime mover) perubahan masyarakat.

Delors (1999) dalam laporannya mengemukakan pentingnya peranan guru sebagai agen perubahan, mengembangkan pengertian dan toleransi belum pernah sejelas sekarang ini. Selanjutnya, Delors mengemukakan bahwa kelihatannya peranan 
guru ini akan lebih penting lagi di dalam abad XXI. Demikian juga Danim(2003) mengemukakan bahwa dari komponenkomponen tersebut di alas, komponen guru mempunyai peranan penting dan merupakan kunci pokok bagi keberhasilan peningkatan mutu pendidikan. Oleh karena itu, menurut Danim kemampuan profesional guru perlu ditingkatkan dan dikembangkan dengan berbagai upaya, antara lain melalui pendidikan, latihan dan pembinaan teknis yang dilakukan secara berkesinambungan di sekolah dan di tempat-tempat pembinaan profesional seperti Kelompok Kerja Guru (KKG), Kelompok Kerja Kepala Sekolah (KKKS) dan kelompok Kerja Penilik Sekolah (KKPS). Peningkatan dan pengembangan kemampauan profesional tersebut meliputi berbagai aspek antara lain kemampuan guru dalam menguasai kurikulum dan materi pengajaran, kemampuan dalam menggunakan metode dan sarana dalam proses belajar-mengajar, melaksanakan penilaian proses dan hasil belajar, dan kemampuan memanfaatkan lingkungan sebagai sumber belajar, disiplin dan komitmen guru terhadap tugas.

Untuk meningkatkan profesionalisme guru, media yang dianggap paling relevan adalah melalui supervisi pengajaran.Karena supervisi adalah pembinaan yang diberikan kepada seluruh staf sekolah agar mereka dapat meningkatkan kemampuan untuk mengembangkan situasi belajar mengajar yang lebih baik (Depdikbud, 1976).Dalam Pedoman Buku III D Administrasi dan Supervisi dijelaskan bahwa usaha meningkatkan mutu pendididikan dan pengajaran sebagian besar terletak pada kegiatan guru dalam mendorong murid-murid kearah tercapainya tujuan pendidikan.Agar tugas mendidik dan mengajar dapat ditingkatkan, maka guru perlu mendapat pembinaan (supervisi) secara teratur dan berencana.Untuk itupara Kepala Sekolah perlu memiliki pengetahuan tentang pengertian, tujuan, fungsi dan teknik supervisi disertai petunjuk pelaksanaan secara sederhana.

Beberapa teknik pembinaan profesional yang dapat digunakan oleh kepala sekolah untuk meningkatkan proses dan hasil belajar antara lain: (1) kunjungan kelas, (2) pertemuan pribadi, (3) rapat dewan guru, (4 penataran, (5) pemanfaatan guru model, (6) penerbitan buletin profesional, (7) pertemuan dalam kelompok kerja, dan sebagainya (Depdikbud, 1994/1995). Dari berbagai teknik pembinaan tersebut, teknik mana yang paling tepat untuk diterapkan, tergantung pada situasi dan kondisi pada masing-masing guru.Setiap pembina harus selalu berupaya untuk dapat meningkatkan kemampuan profesional guru, sehingga guru benar-benar mampu melaksanakan tugas sebagai pendidik.

Sebagai upaya membantu guru dalam memperbaiki proses belajar mengajar, maka seharusnya supervisi dilaksanakan berdasarkan prinsip-prinsip, teknik dan pendekatan yang tepat. Dengan pendekatan yang tepat, diharapkan kemampuan profesional guru dapat ditingkatkan. Sedangkan guru yang profesional adalah guru yang mempunyai ciri-ciri sebagai berikut (1) memiliki suatu keahlian khusus, (2) merupakan suatu panggilan hidup, (3) memiliki teori-teori yang baku secara universal, (4) mengabdikan diri untuk masyarakat dan bukan untuk diri sendiri, (5) dilengkapi dengan kecakapan diagnostik dan kompetensi yang aplikatif, (6) memiliki otonomi dalam melaksanakan pekerjaannya, (7) mempunyai kode etik, (8) mempunyai klien yang jelas, (9) mempunyai organisasi profesi yang kuat, dan (10) mempunyai hubungan dengan profesi pada bidang-bidang yang lain.

Sementara itu mengenai pendekatan supervisi, Glickman (1981) membagi orientasi supervisi pendidikan menjadi tiga, berdasarkan kemampuan guru, yaitu (1)direktif, (2) nondirektif, dan (3) kolaboratif, Pertama, orientasi direktif diterapkan manakala supervisor menemukan guru yang dalam mengembangkan dirinya sendiri sangat rendah, sehingga Pembina harus banyak memberikan petunjuk dengan contoh- contoh kongkrit disertai tugas-tugas. Kedua, orientasi nondirektif digunakan apabila tanggung jawab guru dalam mengembangkan dan membina dirinya sendiri tinggi.Ketiga, orientasi kolaboratif digunakan apabila tanggung jawab antara guru dengan supervisor seimbang.Pembina bersama-sama saling memberi dan saling meminta melalui diskusi, sehingga diperoleh kesepakatan.

Sedangkan Oliva (1984) membagi orientasi supervisi menjadi dua, yaitu: (1) orientasi langsung, dan (2) tidak langsung. Orientasi langsung didasarkan pada asumsi bahwa pengawasan dilakukan atas dasar kewenangan seseorang yang memiliki posisi dalam hierarki organisasi.Sedangkan orientasi tidak langsung didasarkan pada asumsi bahwa pengawasan terhadap situasi tergantung pada tuntutan pada masalah. 
Dalam praktiknya supervisi pengajaran yang dilaksanakan selama ini masih cenderung berorientasi pada administratif saja.Fenomena ini dikaji secara khusus dalam Konferensi Pendidikan.di Indonesia: Mengatasi Krisis Menuju Pembaruan, yang diikuti para pakar yang kompeten. Salah satu rekomendasri dari konferensi

khususnya yang berkaitan langsung dengan masalah supervisi dikemukakan sebagai berikut

\section{Rekomendasi 23}

Fungsi-fungsi pengawasan pada semua jenjang pendidikan dioptimalkan sebagai sarana untuk memacu mutu pendidikan.Pengawasan dimaksud dengan mengutamakan aspek-aspek akademik daripada administratif sebagaimana berlaku selama ini (Jalal \& Supriadi, 2001).

Keefektifan penerapan orientasi dan pendekatan supervisi di atas, tidakhanya tergangtung pada supervisor saja, melainkan juga sangat dipengaruhi oleh persepsi, respon, dan sikap guru terhadap orientasi dan supervisi yang dilakukan oleh supervisor.Penelitian mengenai sikap guru terhadap supervisi dikemukakan oleh Ekosusilo (2003) bahwa guru tidak terlalu positif terhadap supervisi yang dilakukan supervisor.Selanjutnya dikemukakan oleh Ekosusilo dalam simpulan penelitiannya bahwa supervisi yang dilakukan supervisor dianggap biasa-biasa saja dan monoton itu-itu saja, bahkan nampak diacuhkan.Namun guru tidak menampakkan ketidak-setujuannya di hadapan supervisor, karena dilandasi rasa hormat sekaligus tidak ingin menimbulkan konflik.Penelitian yang dilakukan Mantja (1989) juga menyimpulkan bahwa respon dan sikap guru terhadap supervisi ditentukan oleh kemanfaatan, data pengamatan yang obyektif, kesempatan menanggapi balikan, perhatian supervisor terhadap gagasan guru.Supervisi yang teratur dan hubungan yang diciptakan dapat mengurangi ketegangan emosional guru. Guru lebih menyukai pendekatan supervisi kolaboratif atau non direktif.

Dari studi pendahuluan yang peneliti laksanakan, terungkap bahwa masalah peningkatan profesionalisme guru merupakan masalah yang mendapatkan perhatian dari masing-masing kepala sekolah di empat SD tersebut. Demikian juga model pendekatan yang dilakukan oleh keempat kepala sekolah di situs yang berbeda tersebut, walaupun secara teoritis sama, namun pendekatan masing-masing kepala sekolah berbeda.

Tujuan penelitian ini adalah: (1) mendeskripsikan program supervisi pengajaran yang disusun oleh Kepala Sekolah terhadap para guru sekolah dasar dalam rangka meningkatkan profesionalisme guru, (2) menjelaskan prosedursupervisi pengajaran yang diterapkan oleh Kepala Sekolah terhadap para guru sekolah dasar dalam rangka meningkatkan profesionalisme guru, (3) mengidentifikasi teknik-teknik supervisi pengajaran oleh Kepala Sekolah terhadap para guru sekolah dasar dalam rangka meningkatkan profesionalisme guru, (4) mendeskripsikan pola pendekatan supervisi pengajaran yang digunakan oleh Kepala Sekolah terhadap para guru di sekolah dasar dalam rangka meningkatkan profesionalisme guru, (5) menjelaskan respon dan sikap guru sekolah dasar terhadap pelaksanaan supervisi pengajaran yang dilakukan oleh Kepala Sekolah dalam rangka meningkatkan profesionalisme guru, (6) menemukan kendalakendala yang dihadapi Kepala Sekolah dalam melaksanakan supervisi pengajaran terhadap para guru pada empat sekolah dasar dalam rangka meningkatkan profesionalisme guru, dan (7) mendeskripsikan upaya-upaya yang dilakukan oleh Kepala Sekolah dalam melaksanakan supervisi pengajaran di sekolah dasar dalam rangka meningkatkan profesionalisme guru.

\section{METODE PENELITIAN}

Penelitian ini menggunakan rancangan studi multi kasus (multi-case studies) dengan metode komparatif konstan (the constant comparative method). Lokasi penelitian di SD Laboratorium Sumber Ilmu, SDN Sekar Arum I, SDK Sang Surya, dan SDN Madukoro VI Malang.Informan dalam penelitian ini adalah para Kepala Sekolah dan Guru.Teknik pengumpulan data menggunakan (1) wawancara mendalam, (2) observasi partisipan, dan (3) studi dokumentasi.Analisis data dilakukan dua tahap, yaitu (1) analisis data kasus individu, dan (2) analisis data lintas kasus.Pengecekan keabsahan data melalui derajat kepercayaan (credibility),keteralihan (transferability), ketergantungan (dependability), dan kepastian (confirmability).

\section{HASIL DAN PEMBAHASAN}

1. Program Supervisi Pengajaran 
Program supervisi pengajaran disusun pada awal tahun pelajaran sebelum kegiatan belajar mengajar dimulai, dengan memasukkan program tersebut dalam Program Kerja atau RAPBS sebagai acuan Kepala Sekolah untuk melaksanakan kegiatan supervisi pengajaran terhadap para guru di sekolah: (1) program supervisi pengajaran yang disusun oleh Kepala Sekolah bersifat komprehensif dan diarahkan untuk meningkatkan kompetensi dan profesionalisme guru di sekolah; (2) program supervisi pengajaran yang disusun oleh Kepala Sekolah terdiri dari : program semester, dan program bulanan sekaligus juga disusun jadwal supervisi pengajaran yang dilaksanakan pada saat melakukan kunjungan kelas; (3) pelaksanaan supervisi pengajaran oleh Kepala Sekolah terhadap para guru di sekolah dilakukan secara periodik sesuai dengan jadwal supervisi pengajaran yang telah disusun oleh Kepala Sekolah pada tahun ajaran baru; (4) pelaksasaan supervisi pengajaran yang diterapkan oleh Kepala Sekolah diterapkan langkah-langkah sebagai berikut : (a) koordinasi, (b) menjadwal, (c) supervisi, dan (d) tindak lanjut, (5) Kepala Sekolah menggunakan sebagai instrumen dalam pelaksanaan kunjungan kelas sesuai jadwal yang telah disusun, Kepala Sekolah menggunakan lembar observasi monitoring tugas untuk memonitoring kelengkapan administrasi guru dan kegiatan pembelajaran yang dilaksanakan oleh guru di kelas.

\section{Prosedur Supervisi Pengajaran}

Prosedur supervisi pengajaran yang dilaksanakan oleh Kepala Sekolah adalah menyusun program supervisi pengajaran, menerima masukan dan orang tua dan guru pada saat melaksanakan kunjungan kelas, kemudian ditindak lanjuti dengan mengadakan pertemuan baik individual maupun kelompok dalam rapat dewan guru: (1) Kepala Sekolah menyusun jadwal program supervisi kunjungan kelas bersama-sama dengan para guru; (2) Kepala Sekolah melaksanakan supervisi kunjungan kelas berdasarkan jadwal yang telah disusun; (3) apabila dipandang perlu Kepala Sekolah memanggil guru ke ruang Kepala Sekolah untuk melakukan pembinaan secara individual guna memberitahukan kekurangan guru yang bersangkutan tentang proses belajar mengajar serta perbaikan yang perlu dilakukan berdasarkan kunjungan kelas Kepala Sekolah; (4) dalam setiap kunjungan kelas Kepala Sekolah menggunakan lembar obvservasi serta membuat catatan tertulis untuk disampaikan kepada guru yang bersangkutan; (5) pembinaan yang dilakukan oleh Kepala Sekolah bersifat individual (perorangan) secara kekeluargaan maupun secara kelompok dalam rapat dewan guru; (6) Kepala Sekolah mengadakan evaluasi hasil supervisi pengajaran secara keseluruhan pada rapat dewan guru yang dijadwal pada setiap minggu/bulan sesuai dengan kebiasaan atau jadwal yang diprogram oleh sekolah masingmasing; (7) prosedur supervisi pengajaran yang dilaksanakan oleh Kepala Sekolah melalui pentahapan sebagai berikut : kunjungan kelas, pengamatan, permasalahan, identifikasi permasalahan, klarifikasi dan solusi.

\section{Teknik-Teknik Supervisi Pengajaran}

Teknik-teknik supervisi pengajaran yang dilaksanakan oleh Kepala Sekolah antara lain meliputi: pemeriksaan administrasi guru, kunjungan kelas, rapat dewan guru secara rutin, menyediakan bacaan profesional, mengirim guru dalam pendidikan dan pelatihan, penatyaran, seminar, KKG, wawancara pribadi serta menganjurkan untuk studi lanjut bagi yang belum menempuh pendidikan Si: (1) pemeriksaan administrasi guru yang dilaksanakan oleh Kepala Sekolah antara lain meliputi: (a) khusus jurnal tiap minggu, (b) silabus, (c) data rekap nilai tiap Mid dan Semester dan absensi, (d) agenda tiap minggu (murid) untuk mengetahui program mengajar tiap hari dan volume PR/tugas di luar sekolah), (e) analisis hasil penilaian (tiap ulangan), (f) program perbaikan-pengayaan, (g) program semester, dan (h) program ulangan semester; (2) apabila Kepala Sekolah melakukan kunjungan kelas, maka Kepala Sekolah duduk di bangku paling belakang dan mengamati proses belajar mengajar yang dilaksanakan oleh guru dengan menggunakan lembar observasi kelas/angket, dari pengamatan yang dilakukan akan dapat diidentifikasi kekurangan-kekurangan guru dalam mengelolan proses belajar mengajar untuk selanjutnya dilakukan pembinaan kepada guru yang bersangkutan; (3) pada saat rapat dewan guru yang dijadwalkan secara periodik, dilaksanakan sharing antara guru dengan guru, guru dengan Kepala Sekolah, pemberian motivasi kepada para guru, serta mencari solusi terhadap permasalahan yang dihadapi para guru; (4) dalam melaksanakan teknik-teknik supervisi, Kepala Sekolah disamping mengadakan supervisi kunjungan kelas, pemeriksaan kelengkapan administrasi guru Kepala Sekolah 
juga mengadakan pengamatan dan luar (lingkungan); dan (5) Kepala Sekolahmelaksanakan teknik supervisi yang sifatnya perorangan/individual dengan cara mengadakan pertemuan langsung secara perorangan dan dilakukan dialog (wawancara pribadi).

\section{Pola Pendekatan Supervisi Pengajaran}

Pola pendekatan supervisi pengajaran yang dilaksanakan oleh Kepala Sekolah bersifat langsung maupun tidak langsung, personal/individual maupun kelompok, pemeriksaan administrasi guru dan pertemuan kasus serta penggunaan media secara lisan dan tertulis serta dengan pendekatan secara kekeluargaan: (1) Proposisi minor : pendekatan supervisi pengajaran oleh Kepala Sekolah terhadap para guru yang bersifat langsung adalah dengan mengadakan kunjungan ke kelaskelas baik yang terjadwal maupun yang tidak terhjadwal (dadakan); (2) pendekatan supervisi pengajaran oleh Kepala Sekolah yang bersifat tidak langsung adalah dengan menerima masukan dari orang tua tentang pelaksanaan kegiatan belajar mengajar yang dilaksanakan oleh guru melalui saluran komunikasi yang disiapkan oleh sekolah; (3) pendekatan yang dilaksanakan oleh Kepala Sekolah dapat bersifat personal (perorangan) maupun bersifat kelompok dalam rapat koordinasi yang dilaksanakan secara rutin; (4) pendekatan yang dilaksanakan oleh Kepala Sekolah yang bersifat pendekatan administrasi, pada saat ini kelengkapan administrasi administrasi guru yang diperiksa oleh Kepala Sekolah antara lain : a) KBK ta-hun 2004/pemetaan kurikulum, (b) Kalender pendidikan, (c) Program se-mester, (d) Rencana pembelajaran, (e) Silabus, lembar pengamatan, (f) Alat peraga, dan (g) Bank Soal; (5) walaupun menyampaikan teguran atau pemberitahuan Kepala Sekolah melakukanpendekatan yang bersifat kekeluargaan, ramah dan obyektif, sehingga mudah diingat dan dilaksanakan, juga guru merasa didukung, diberi pengalaman dan guru akan melaksanakan tugas tanpa paksaan, dan (6) apabila Kepala Sekolah mengadakan pendekatan secara kelompok, maka materi yang disampaikan adalah evaluasi kegiatan, tanya jawab tentang pelaksanaan KBM, memberi saran dan kritik yang membangun, catatan hasil penataran/pelatihan, hasil rapat dengan Pengawas/Dinas, hasil rapat dengan KKKS, pengalaman pribadi selama mengajar, pemberian penguatan pada guru, dan memberi kesempatan/kepercayaan pada guru untuk mengembangkan kemampuan guru tersebut, tanpa harus selalu didekte.

\section{Respon dan sikap guru terhadap pelaksanaan supervisi pengajaran oleh Kepala Sekolah}

Respon dan sikap guru terhadap supervisi pengajaran yang dilaksanakan oleh Kepala Sekolah pada dasarnya positif dan mendukung program-program supervisi pengajaran Kepala Sekolah, karena menurut para guru supervisi pengajaran dapat memberikan kontribusi bagi peningkatan kompetensi guru dan kualitas belajar mengajar: (1) guru menyambut baik dan positif pelaksaanan supervisi pengajaran yang dilaksanakan oleh Kepala Sekolah, karena menurut mereka memberikan kontribusi bagi peningkatan kualitas proses belajar mengajar; (2) Kepala Sekolah diharapakan oleh para guru mempunyai jadwal khusus untuk melaksanakan supervisi pengajaran secara teratur dan tertib; (3) para guru mendukung pelaksanaan supervisi pengajaran oleh Kepala Sekolah, karena program ini dapat meningkatkan kompetensi guru; (4) apabila KepalaSekolah melaksanakan supervisi pengajaran, maka guru terpacu until disiplin, terampil, teratur melaksanakan tugastugasnya, terbiasa memanfaatkan waktu dengan baik, dan secara bertahap lebih baik dan waktu sebelumnya; (5) pengembangan bahan ajar dengan kreatifitas, administrasi yang teratur, waktu yang efisien merupakan unsur-unsur yang dapat memberikan kontribusi dalam rangka rangka meningkatkan profesionalisme guru; (6) respon guru terhadap pelaksanaan supervisi pengajaran ditunjukkan dengan kinerja para guru dalam melaksanakan tugas-tugas di sekolah, seperti : setiap guru membuat persiapan, analisis dan administrasi lain yang diperlukan dalam pembelajaran, masingmasing melaksanakan tugas dengan penuh tanggung jawab, dan tidak ada yang membolos/jarang ada yang ijin; (7) guru selalu melaksanakan tugastugas yang diberikan oleh Kepala Sekolah walaupun diberikan tugas tambahan di luar kegiatan belajar mengajar (KBM); (8) supervisi pengajaran yang dilaksanakan oleh Kepala Sekolah terhadap para guru, dapat meningkatkan meningkatkan motivasi (semangat) dalam mengajar serta dapat meningkatkan prestasi belajar siswa, dan (9) dengan pelaksanaan supervisi pengajaran yang dilaksanakan oleh Kepala Sekolah akan dapat mengevaluasi 
kekurangan guru dalam mengajar, sehingga guru dapat meningkatkan kegiatan belajar mengajarnya serta dapat meningkatkan prestasi belajar peserta didik.

\section{Kendala-kendala Pelaksanaan Supervisi Pengajaran}

Kendala-kendala yang mempengaruhi Kepala Sekolah dalam melaksanakan supervisi pengajaran terhadap para guru antara lain adalah keterbatasan waktu, sarana dan prasarana, dana, terbatasnya peran masyarakat, kesejahteraan guru,kurangnya pelatihan, tingkat kemampuan siswa yang heterogen, dan wali murid yang kurang pro aktif terhadap kegiatan sekolah: (1) kendala pelaksanaan supervisi pengajaran oleh Kepala Sekolah terhadap para guru di sekolah dikarenakan adanya kunjungan kelas yang telah dijadwalkan sering bersamaan dengan acara kedinasan lainnya yang lebih penting; (2) para guru mengemukakan bahwa kendala-kendala dalam rangka peningkatan kualitas belajar mengajar adalah terbatasnya sarana dan parasana serta media pengajaran yang modern (canggih) yang terdapat di sekolah; dan (3) rendahnya frekuensi para guru yang mengikuti pendidikan dan pelatihan serta tingkat kesejahteraan guru yang masih rendah menjadi kendala bagi Kepala Sekolah dalam melaksanakan supervisi pengajaran terhadap para guru.

7. Upaya-upaya yang dilakukan oleh Kepala Sekolah dalam Melaksanakan Supervisi Pengajaran di Sekolah Dasar dalam rangka Meningkatkan Profesionalisme guru di Sekolah Dasar

Upaya Kepala Sekolah dalam meningkatkan profesionalisme guru melalui supervisi pengajaran antara dilakukan dengan cara menciptakan hubungan yang baik antara guru dengan kepala sekolah, melakukan pembinaan kepada para guru secara periodik serta mengevaluasi kegiatan belajar mengajar dan melakukan perbaikan, mengadakan rapat dengan dewan guru, mengikutkan guru ke penataran, KKG, lomba guru berprestasi, serta meningkatkan kinerja guru: (1) Kepala Sekolah menyusun jadwal program supervisi pengajaran kepada para guru secara periodik serta mengevaluasi kelemahan-kelemahan dalam proses belajar mengajar untuk kemudian dilakukan perbaikan; (2) Kepala Sekolahmengikutkan guru dalam lomba guru berprestasi, mengirim guru untuk mengikuti lokakarya, seminar dan KKG; (3) Kepala Sekolah menciptakan suasana lingkungan kerja yang kondusif bagi terselenggaranya proses belajar mengajar di sekolah dengan cara menjaga kekompakan guru, sating menghormati, menerapkan kedisiplinan kerja, dan menjalin hubungan antara sekolah dengan orang tua siswa/masyarakat sekitar sekolah dalam rangka untuk meningkatkan profesionalisme guru di sekolah; (4) sesuai dengan kebutuhan sekolah, Kepala Sekolah mengadakan pelatihan di sekolah dengan mengundang orang yang ahli untuk memberikan pelatihan kepada pars guru dalam rangka peningkatan kompetensi guru dalam mengelola kegiatan belajar mengajar; dan (5) dalam rangka meningkatkan profesionalisme guru, Kepala Sekolah menganjurkan kepada guru yang usianya masih relatif muda dan belum memiliki kualifikasi pendidikan setara Si untuk mengikuti studi lanjut pada program S1 kependidikan atau program penyetaraan.

\section{KESIMPULAN DAN SARAN \\ Kesimpulan}

Temuan penelitian anatara lain: (1) Penyusunan program supervisi pengajaran yang ditujukan kepada para guru di sekolah dasar disusun oleh Kepala Sekolah dan penyusunannya dilakukan pada awal tahun ajaran bare dengan memasukkan program ini dalam RAPBS (Rencana Anggaran Penerimaan dan Belanja Sekolah). Dalam program supervisi pengajaran yang disusun Kepala Sekolah ini disusun pula jadwal supervisi dan monitoring ke kelas-kelas yang akan dilaksanakan selama satu tahun pelajaran dan diarahkan untuk meningkatkankompetensi guru di sekolah. Sedangkan untuk pelaksanaan supervisi pengajaran dipersiapkan instrumen-instrumen monitoring dan evaluasi, (2) Prosedur supervisi pengajaran yang dilaksanakan oleh Kepala Sekolah di empat situs yang terteliti dengan menggunakan tahapan sesuai dengan pola baku yang dianjurkan oleh Dinas Pendidikan ataupun tahapan siklus supervisi klinis, namun dalam praktiknya di masing-masing situs berbeda, ada tahapan yang tidak diterapkan secara penuh, sehingga pelaksanaannya tidak sama di masingmasing situs, (3) Teknik-teknik supervisi pendidikan yang dilaksanakan oleh Kepala Sekolah di setiap situs cukup bervariasi antara situs yang satu dengan situs lainnya, walaupun tujuannya sama yaitu untuk meningkatkan kompetensi guru agar lebih profesional. Teknikteknik supervisi yang hampir sama dilaksanakan 
di empat situs terteliti adalah rapat dewan guru, kunjungan kelas, pemeriksaan administrasi, perpustakaan profesional serta memotivasi guru untuk meningkatkan kompetensi melalui latihan dan studi lanjut, (4) Pola pendekatan Supervisi Pengajaran yang diterapkan oleh Kepala Sekolah terhadap para guru di sekolah dasar dalam pelaksanaan supervisi pengajaran di sekolah dasar adalah langsung (kunjungan ke kelas kelas) dan tidak langsung (melalui orang tua siswa) dengan pembinaan yang bersifat individual maupun pembinaan yang bersifat kelompok dengan tetap mengutamakan pendekatan kekeluargaan, (5) Sikap dan respon guru terhadap supervisi pengajaran yang dilaksanakan oleh Kepala Sekolah cukup positif, karena pelaksanaan supervisi pengajaran yang dilaksanakan oleh Kepala Sekolah ada hubungan yang signifikan dengan upaya peningkatan kualitas proses belajar mengajar di kelas. Di samping itu dengan supervisi pengajaran akan diketahui kekurangan-kekurangan yang ada pada guru serta ada tindakan perbaikan lebih lanjut, 6) Kendala-kendala yang dihadapiKepala Sekolah dalam melaksanakan supervisi pengajaran di sekolah dasar adalah masalah dana, terbatas sarana dan prasarana, kurangnya pelatihan, kesejahteraan guru serta kurangnya pelatihan bagi guru tentang model-model keterampilan proses yang dapat diterapkan kepada peserta didik, (7) Dalam rangka meningkatkan profesionalisme guru, Kepala Sekolah melalui supervisi pengajaran melaksanakan upaya-upaya sebagai berikut: melaksanakan kunjungan kelas, monitoring $\mathrm{KBM}$, rapat dewan guru, pembinaan secara individu maupun kelompok, bacaan profesional, studi lanjut, mengikutkan guru dalam KKG, penataran/lokakarya/seminar, sharing dan diskusi antar guru, guru dengan kepala sekolah, guru dengan pengawas.

\section{Saran-saran}

Berdasarkan temuan temuan penelitian di atas, dikemukakan saran-saran sebagai berikut. (1) Bagi Kepala Sekolah, disarankan dalam program supervisi pengajaran dipersiapkan pula instrumen-instrumen yang nantinya akan digunakan untuk untuk melaksanakan evaluasi monitoring kegiatan belajar mengajar, (2) Bagi Dinas Pendidikan Kota Malang, disarankan kepada Dinas Pendidikan Kota Malang untuk menyelenggarakan pendidikan dan pelatihan kepada para Kepala Sekolah atau Calon Kepala Sekolah tentang penerapan prosedur supervisi
Minis, (3) Bagi Dinas Pendidikan Kota Malang, khsusnya Bidang Pendidikan Dasar, perlu ada pelatihan bagi Kepala Sekolah mengenai teknikteknik supervisi pengajaran yang dapat diterapkan terhadap para guru di sekolahdasar, sehingga diharapkan dengan adanya pelatihan tersebut dapat membantu Kepala Sekolah agar dalam menerapkan teknik-teknik supervisi pengajaran lebih bervariasi, efisien dan efektif serta dapatdigunakan untuk meningkatkan kualitas kegiatan belajar mengajar, (4) Perlu disusun pedoman supervisi pengajaran bagi para Kepala Sekolah agar ada keseragaman dalam menerapkan pola-pola pendekatan supervisi pengajaran bagi para guru di sekolah dasar dengan diprakarsai oleh K3S serta Pengawas Sekolah dan Kepala UPTD di Kecamatan yang ada di wilayah kota Malang (5) Supervisi yang dilaksanakan oleh kepala sekolah sebaiknya tidak terfokus pada administrasi guru (kelengkapan administrasi pengajaran guru) saja, melainkan juga proses belajar mengajar yang dilaksanakan oleh guru, (6) Untuk meningkatkan wawasan guru tentang metode pemecahan masalah-masalah kelas, maka para guru perlu dibekali pengetahuan dan keterampilan tentang PTK (Penelitian Tindakan Kelas).

\section{DAFTAR PUSTAKA}

Achmady, Z.A. 1995. Reformasi Administrasi dalam Pendidikan: Beberapa Pelajaran tentang Implementasi Kebijakan', Pidato Pengukuhan Jabatan Guru Besar. Malang: Universitas Brawijaya.

Adan, A.M. 1987.Analisis Kebutuhan, Pengadaan dan Pengembangan Kepala Sekolah Dasar Negeri di Propinsi Daerah Istimewa Aceh (http://ppsupi.org/abstraksi.htm).Diakse s 9 Januari 2006.

Badan Akreditasi Sekolah (BAS) Kota Malang. 2005. Surat Keputusan BAS Kota Malang Nomor: 01/Kep/BASKOTA/I/2005 tentang Penetapan Hasil Akreditasi Sekolah. Malang: Badan Akreditasi Sekolah (BAS) Kota Malang.

Bafadal, I. 1994. Proses Perubahan di Sekolah, Studi Multisitus pada Tuga Sekolah Dasar yang Baik di Sumekar.Disertasi tidal( diterbitkan. Malang: Program Pasca Sarjana, Institut Keguruan dan Ilmu Pendidikan Malang. 
Brodjonegoro, S.S. 2004. Kualifikasi Pendidikan untuk Guru Kelas Sekolah Dasar, (Oniline), (www.dikti.orgkualifikasiGuruSD.htm, diakses 11 januari 2006).

Brannen, J. 1992. Mixing Methods: Qualitative and Quantitative Research.Aldershot, England: Avebury.

Caillods, F. 2004. Teachers: a Priority. News Letter, (Online), Vol. XXII, No. 1, January-March 2004 (http://www.unesco.org/iiep, diakses 17 Januari 2006).

Danim, S. 2002. Inovasi Pendidikan, Dalam Upaya Peningkatan Profesionalisme Tenaga Kependidikan. Bandung: Pustaka Setia.

Danumihardja, Hj.M. 2004.Manajemen Keuangan Sekolah, Studi Manajemen Keuangan pada Sekolah Lanjutan Tingkat Pertama dalam Implementasi Otonomi Daerah. Jakarta: Uhamka Press.

Ekosusilo, M. 2003. Hasil Penelitian Kualitatif, Supervisi Pengajaran Dalam Latar Budaya Jawa, Studi Kasus Pembinaan Guru SD di Kraton Surakarta. Sukoharjo: Penerbit Uvitet Bantara Press.

Elley, W.B. 1992. How in the World Do Students Read.The Hague: IEA.

Ellis, A.J., Cogan, J.J. \& Howey K.R. 1991.Introduction to the Foundations of Education.Boston: Allyn and Bacon.

Engkoswara, Soemantri, H.M, Ibrahim, R. \& Sudjana, N. 2000.Keefektifan Program Pendidikan Guru Sekolah Dasar.Jurnal Ilmu Pendidikan, I (2): 107-114.

Fattah. N. 1987. Ketidak Sesuaian Antara Anggaran yang Diusulkan dengan Anggaran yang Disetujui Dalam Program Peningkatan Mutu Pendidikan SMA di Jawa Barat.Bandung.

Gaffar, H.M.F. 2004.Membangun Kembali Pendidikan Nasional dengan Fokus: Pembaharuan Manajemen Perguruan Tinggi Pada Era Globalisasi.

Makalah disajikan dalam Konvensi Nasional Pendidikan Indonesia V, Surabaya, 5-9 Oktober 2004.

Gaustad, J. 1992. School Discipline.Digest \# 78, December.
Gay, L.R. 1987. Educational Research, Competencies for Analysis and Application.Third Edition. Columbus, Ohio: Merrill Publishing Company.

Glaser, B.G. \& Strauss, A.L. 1980.The Discovery of Grounded Theory, Strategies for Qualitative Research. New York: Aldine Publishing Company.

Glaser, B.G. \& Strauss, A.L. 1985.Penemuan Teori Grounded, Beberapa Strategi Penelitian Kualitatif. Terjemahkan oleh Abd.Syukur Ibrahim dan Machrus Syamsuddin. Surabaya: Usaha Nasional.

Glickman, C.D.1990. Supervision of Instruction, A Developmental Approach. Second Edition. Needham Heights, Massachusetts: Allyn and Bacon.

Gordon, T. 1996. Guru yang Efektif, Cara untuk Mengatasi Kesulitan dalam Kelas.Terjemahan oleh Mudjito. Jakarta: RajaGrafindo Persada.

Gorton, R.A. 1976. School Administration: Challenge and Opportunity for Leadership. Dubugue - Iowa: Wm.C.Brown Company Publishers. 